\title{
First record of the nonnative African catfish, Clarias gariepinus (Burchell, 1822) (Siluriformes: Clariidae), in the D'Una River Basin in Santa Catarina State, Brazil
}

\author{
Rafael Almeida da Silveira * \\ Fábio Rodrigo de Alcântara Lopes \\ José Angel Alvarez Perez \\ Centro de Educação de Ciências Tecnológicas, da Terra e do Mar, Universidade do Vale do Itajaí \\ Rua Uruguai, 458, Caixa Postal 360, CEP: 88302-901, Itajaí - SC, Brazil \\ * Correspondence author \\ silveirara@hotmail.com
}

Submetido em 26/06/2017

Aceito para publicação em 27/02/2018

\section{Resumo}

Primeiro registro do bagre africano Clarias gariepinus (Burchell, 1822) na bacia do rio D'Una no Estado de Santa Catarina, Brasil. Clarias gariepinus é conhecida mundialmente com uma espécie invasora, introduzida principalmente pela aquicultura, com impacto bastante documentado sobre a fauna nativa. Três indivíduos de Clarias gariepinus foram capturados por um pescador artesanal na bacia do Rio D'una, no estado de Santa Catarina. Este trabalho documenta a primeira ocorrência dessa espécie nessa área, ampliando sua ocorrência em águas continentais brasileiras, e discute os potenciais impactos de sua introdução.

Palavras-chave: Espécies exóticas; Neotropical; Peixes

\section{Abstract}

Clarias gariepinus is an invasive species worldwide, which has been introduced mainly by aquaculture, and its impact on native fauna is well documented. Three individuals of $C$. gariepinus were captured by an artisanal fisherman in the D'Una River Basin in Santa Catarina State, Brazil. This paper documents the first record of $C$. gariepinus in this area, indicating an additional spot of occurrence in Brazilian inland waters, and discusses the potential impacts of this introduction.

Key words: Alien species; Fish; Neotropical 
Clarias gariepinus is a widespread African freshwater fish species that occurs naturally from the Nile to the Orange River and is an invasive species worldwide that has spread primarily due to aquaculture (CAMBRAY, 2003). It is resistant to adverse environmental conditions (SEEGERS, 2008) and can tolerate very low oxygen concentrations. This species can also survive for considerable periods out of water due to a specialized suprabranchial organ (HECHT et al., 1988) that is specifically adapted for breathing air (MAINA; MALOIY, 1986), which allows it to move over land (JOHNELS, 1957). It is an omnivorous aquatic feeder (TEUGELS, 1986) that captures a wide variety of prey in diverse habitats (e.g., ponds, lakes and rivers) during its life cycle (KADYE; BOOTH, 2012), including young birds, rotting flesh and plants (DE MOOR; BRUTON, 1988).

This species was previously reported in several basins and aquatic regions in Brazil (WEYL et al., 2016). It is considered a growing threat for aquatic biodiversity due to its great invasive potential throughout the country and, consequently, impact on native species and loss of ecological services (VITULE et al., 2006; ROCHA, 2008; WEYL et al., 2016). The negative impact of species invasions on the fishing economy has already been documented in Brazil (ALVES et al., 2007), highlighting the need for early detection and understanding of the invasion process by aggressive invasive species, such as Clarias gariepinus, to ultimately avoid ecosystem and socioeconomic damage.

This paper reports the first record of Clarias gariepinus in the D'Una River and Mirim Lake, which are both in the D'Una River Basin in Santa Catarina State, southern Brazil, and discusses the potential impacts of this nonnative species.

The D'Una River Basin is $544 \mathrm{~km}^{2}$ and belongs to the Tubarão River and lacustrine system (also known as the Laguna Estuarine System), a coastal river system in southern Brazil formed by the Tubarão River and D'Una River Basin and connected to the Atlantic Ocean (Figure 1). This basin has high social-economic

FIGURE 1: Sites where individuals of Clarias gariepinus were captured.

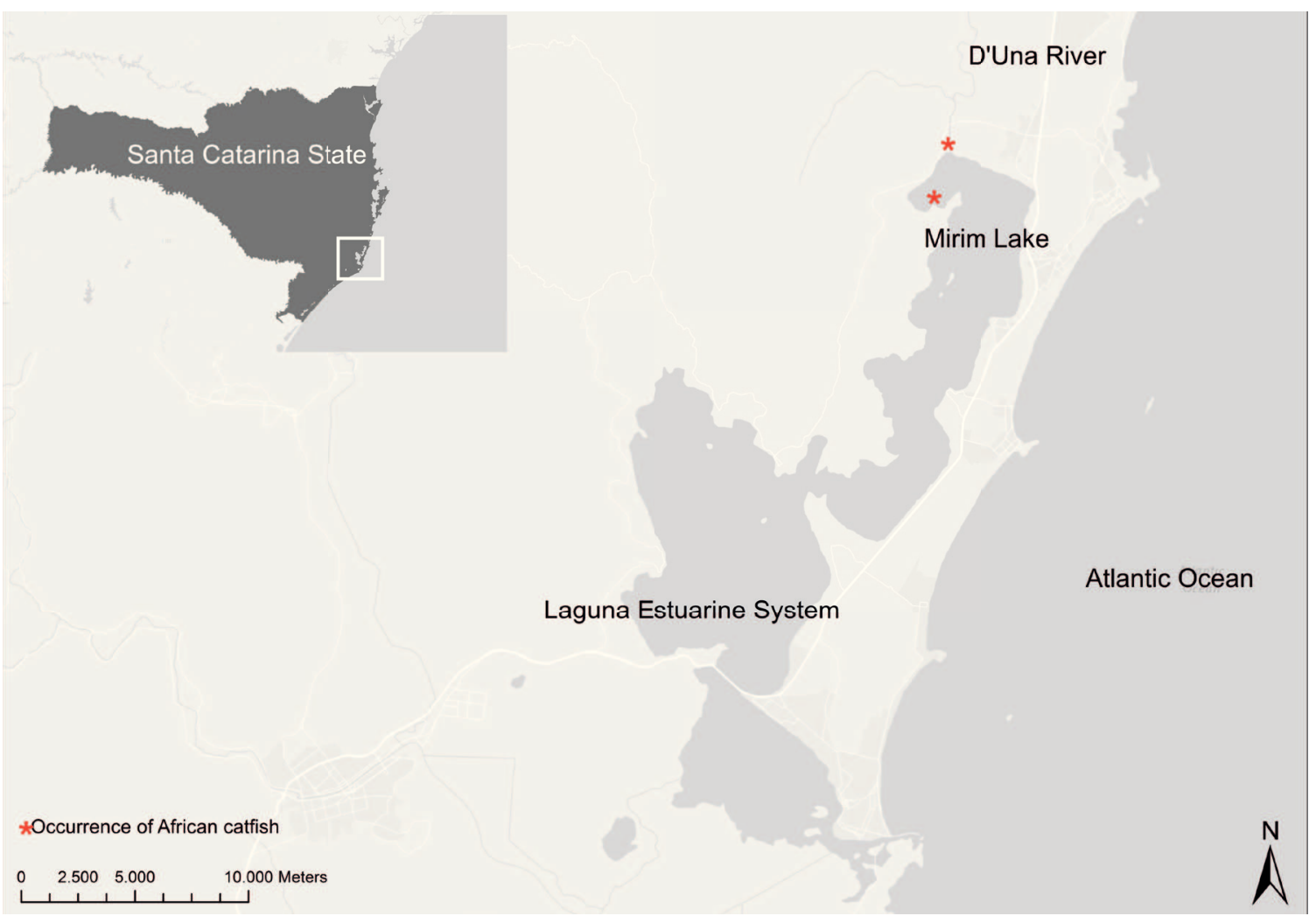


importance for artisanal fisheries and has several important native commercial species, especially the highly valuable pinky shrimp (SUNYE et al., 2014), which is potentially vulnerable to this predator.

We monitored the fisheries of local artisanal fishermen in the D'Una River Basin region, each week from July to December 2016, by checking individual captures using a structured set of questions about fishing gear and techniques, fishing sites and species collected. This was part of the Projeto de Monitoramento da Atividade Pesqueira de Santa Catarina (PMAP-SC) led by the Grupo de Estudos Pesqueiros (GEP) at the Universidade do Vale do Itajaí - UNIVALI.

In October 2016, three individuals of Clarias gariepinus were caught by a local fisherman using a cast net and a small boat. Two of the specimens were caught in the D'Una River (approximately $28^{\circ} 13^{\prime} 4.44$ 'S, 48 44'27.43” W) and one was caught in Mirim Lake (approximately $28^{\circ} 14^{\prime} 19.15^{\prime \prime} \mathrm{S}, 48^{\circ} 43^{\prime} 29.46^{\prime \prime} \mathrm{W}$ ). The specimens were identified using Teugels (1986) and Seegers (2008). The individuals had total lengths of 50.5 $\mathrm{cm}, 49 \mathrm{~cm}$ and $44 \mathrm{~cm}$ and weighed $1.13 \mathrm{~kg}, 0.94 \mathrm{~kg}$ and $0.62 \mathrm{~kg}$, respectively. The specimens were deposited in the fish collection at the Federal University of Rio Grande do Sul (UFRGS) as UFRGS 22876, UFRGS 22877 and UFRGS 22878.

Investigations of nonnative freshwater fish have confirmed the existence of significant ecological impacts across multiple levels of biological organization from genes to ecosystems (CUCHEROUSSET; OLDEN, 2011). The African catfish is a hard predator, thus posing a serious potential threat to native fish fauna (VITULE et al., 2006), including the commercial fish and shrimp in this system.

Although this species had already been documented in Brazilian inland waters in the last three decades (WEYL et al., 2016), this record of Clarias gariepinus documents a recent introduction in Brazil, and the

FIGURE 2: Dorsal and lateral views of a Clarias gariepinus specimen (UFRGS 22876 - total length: $50.5 \mathrm{~cm}$ ) collected in the D'Una River Basin.

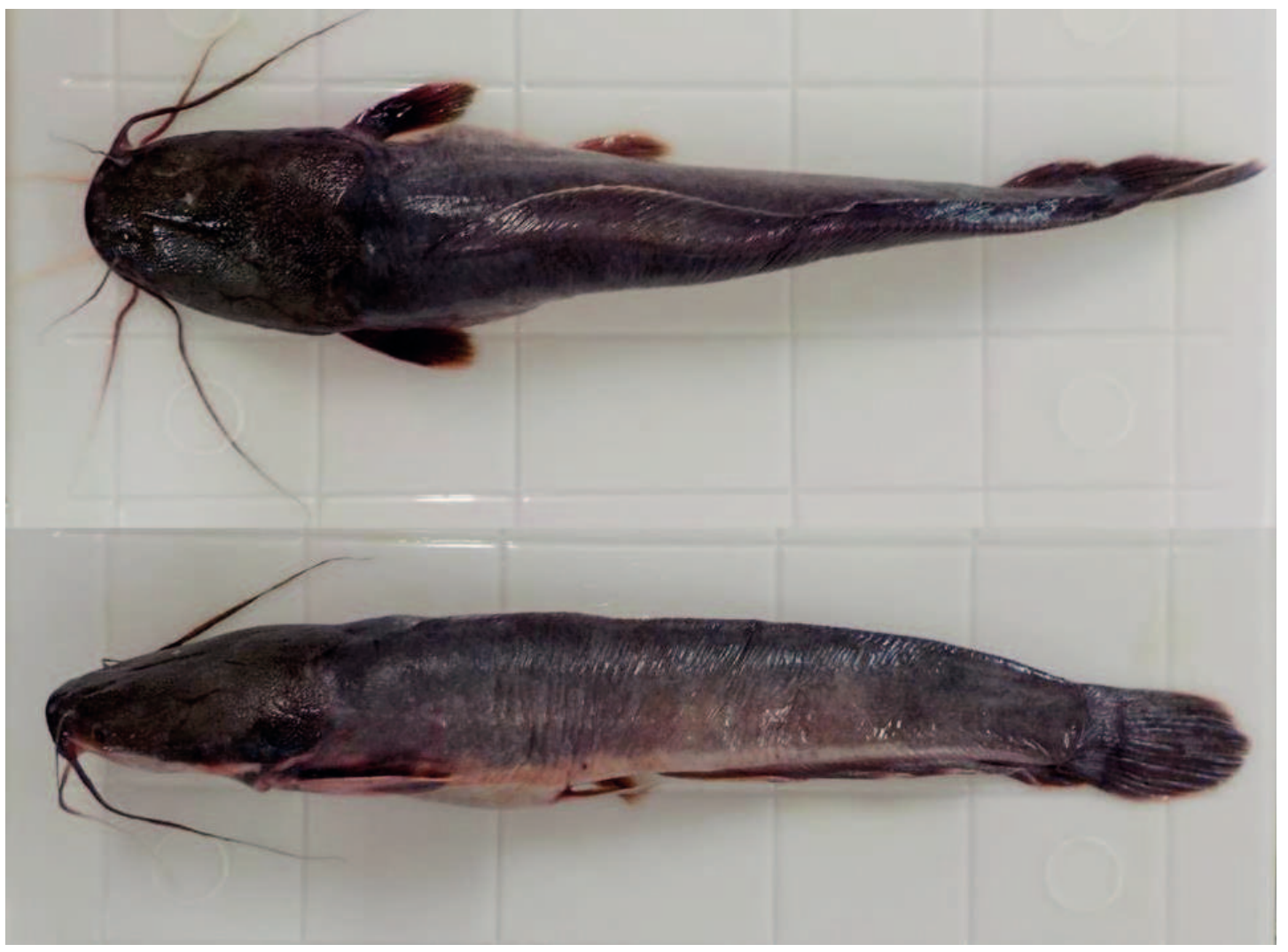


occurrence of this species had never been documented for the D'Una River Basin. Due to the capacity to breathe and disperse over land, these specimens may have escaped from nearby aquaculture tanks or private fish ponds. Escapes from aquaculture tanks are known to be the main introduction mechanism for this and other nonnative species in Brazil (VITULE et al., 2006; LIMA et al., 2016; WEYL et al., 2016).

Species invasion is a complex process, in which introduction is the first step, and can result in a species becoming fully establish and widely distributed in the natural environment. Therefore, successful management measures to prevent biological invasions depend on early detection of the invasion process (KOLAR; LODGE, 2001). Due to the ecological-economic vulnerability of this system to the biological features of Clarias gariepinus, further studies are needed to understand the magnitude of this potential invasion process in this river basin.

\section{References}

ALVES, C. B. M.; VIEIRA, F.; MAGALHÃES, A. L. B.; BRITTO, M. F. G. Impacts of nonnative fish species in Minas Gerais, Brazil: present situation and prospects. In: BERT, T. M. (Ed.). Ecological and genetic implications of aquaculture activities. Dordrecht, Springer Press, 2007. p. 291-314.

CAMBRAY, J. A. The need for research and monitoring on the impacts of translocated sharptoothed catfish, Clarias gariepinus, in South Africa. African Journal of Aquatic Science, Howick, v. 28, n. 2, p. 191-195, 2003.

CUCHEROUSSET, J.; OLDEN, J. Ecological impacts of nonnative freshwater fishes. Fisheries, Bethesda, v. 36, n. 5, p. $215-$ 230, 2011.

DE MOOR, I. J.; BRUTON, M. N. Atlas of alien and translocated indigenous aquatic animals in southern Africa. A report of the Committee for Nature Conservation Research National Programme for Ecosystem Research. Port Elizabeth: South African Scientific Programmes Report no 144, 1988. 310 p.
HECHT, T.; UYS, W.; BRITZ, P. J. (Ed.). Culture of sharptooth catfish, Clarias gariepinus, in southern Africa. Grahamstown: National Scientific Programmes Unit: CSIR, SANSP Report 153, 1988. $146 \mathrm{p}$.

JOHNELS, A. G. The mode of terrestrial locomotion in Clarias. Oikos, Copenhagen, v. 8, p. 122-129, 1957.

KADYE, W. T.; BOOTH, A. J. Integrating stomach content and stable isotope analyses to elucidate the feeding habits of nonnative sharptooth catfish Clarias gariepinus Biological Invasions, Dordrecht, v. 14, n. 4, p. 779-795, 2012.

KOLAR C. S.; LODGE D. M. Progress in invasion biology: predicting invaders. Trends in Ecology \& Evolution, London, v. 16, n. 4, p. 199-204, 2001.

LIMA, L. B.; OLIVEIRA, F. J. M.; GIACOMINI, H. C.; LIMAJUNIOR, D. P. Expansion of aquaculture parks and the increasing risk of nonnative species invasions in Brazil. Reviews in Aquaculture, Medford, DOI: 10.1111/raq.12150, 2016.

MAINA, J. N.; MALOIY, G. M. O. The morphology of the respiratory organs of the African air-breathing catfish (Clarias mossambicus): a light, electron and scanning microscopic study, with morphometric observations. Journal of Zoology, London, v. 209, n. 3, p. 421-445, 1986.

ROCHA, G. R. A. The introduction of the African catfish Clarias gariepinus (Burchell, 1822) into Brazilian inland waters: a growing threat. Neotropical Ichthyology, Maringá, v. 6, n. 4, p. 693-696, 2008 .

SEEGERS, L. The catfishes of Africa: a handbook for identification and maintenance. Rodgau: Aqualog Verlag A.C.S. Gmbh, 2008. $604 \mathrm{p}$.

SUNYE, S. S.; PEREIRA, T. J.; RUSSO, A.; NETO, S. A. A pesca do camarão rosa no sistema estuarino de Laguna, SC: história e acasos das politicas de manejo. In: HAIMOVICI, M.; SUNYE, S. S. (Org.). A pesca marinha e estuarina no Brasil: estudos de caso multidisciplinares. Rio Grande: Editora da FURG, 2014. p. 75-85.

TEUGELS, G. G. A systematic revision of the African species of the genus Clarias (Pisces; Clariidae). Annales du Musée Royal de l'Afrique Centrale, Tervuren, v. 247, p. 1-199, 1986.

VITULE, J. R. S.; UMBRIA, S. C.; ARANHA, J. M. R. Introduction of the African catfish Clarias gariepinus (Burchell, 1822) into Southern Brazil. Biological Invasions, Dordrecht, v. 8, p. 677-681, 2006.

WEYL, O. L. F.; DAGA, V. S.; ELLENDER, B. R.; VITULE J. R. S. A review of Clarias gariepinus invasions in Brazil and South Africa. Journal of Fish Biology, Malden, v. 89, n. 1, p. 386-402, 2016. 